\title{
Critical Issues of Comprehensive Performance Measurement and Management Process
}

\author{
Ing. Michaela Striteska, Ph.D. ${ }^{10000-1111-2222-3333]}$ and Ing. Lucie Jelinkova, Ph.D. ${ }^{2[1111-}$ \\ ${ }^{1}$ University of Pardubice, Faculty of Economics and Administration, Institute of Business \\ Economics and Management, Studentska 95, Pardubice 532 10, Czech Republic, \\ michaela.striteska@upce.cz \\ ${ }^{2}$ University of Žilina, Faculty of Management Science \& Informatics, Department of Manage- \\ ment Theories, Univerzitná 8215/1, 01026 Žilina, Slovakia, lucie.jelinkova @fri.uniza.sk
}

\begin{abstract}
An effectively functioning performance management process has become the key to success in today's tough competitive environment. It is necessary to have comprehensive knowledge of new approaches to performance measurement in order to create and implement such a process. The main aim of this paper is to contribute toward building on such knowledge by designing a performance measurement and management process diagram.

To fulfill this goal, the features of a performance measurement system have been determined based on research in the literature; additionally, key elements that are necessary for a comprehensive process of performance management have been defined using case study analysis. The diagram also identifies critical elements of contemporary performance management process related to the provision of balanced performance indicators and their subsequent incorporation in strategic planning. The findings show that competitive-related performance aspects such as innovation, core competencies, and employee engagement are not sufficiently integrated in performance measurement.
\end{abstract}

Keywords: Performance, Management, Measurement, Process, Indicators.

\section{Introduction}

With the advent of new management practices such as total quality management and lean management as well as new competitive challenges such as flexibility and a rapid response to customer expectations, many have argued that accounting-based performance measurement systems are no longer sufficient (Chow et al., 2006). Similarly, Eccles (1991) stated in the early 90s: "Within the next five years, every company will have to redesign how to measure its business performance."

Performance measurement systems play a key role in implementing strategy, evaluating and understanding the achievement of a company's objectives, and rewarding employees. Many managers and academicians soon recognized that traditional financial indicators are not adequate to fulfill these functions, because they promote shorttermism leading to a lack of strategic focus and failure to provide data on quality 
(Dixon et al., 1990; Bititci, 1994; Kagioglou et al., 2001; Robinson et al., 2005; Wagner, 2009). On the basis of these findings, a wide variety of performance measurement and management systems were developed and implemented. All of them were designed to provide an integrated and balanced overview of a company's performance. This can be considered a key transformation of the period up to 2000. Although much is being written about non-financial performance measures, there is still very little known about actual current practices.

The integration of a multistakeholder perspective and system dynamics is typical in the second decade of the 21st century (Yadav et al., 2013). The most recent literature highlights that it is necessary to approach performance management from a more open systems perspective (Gomes et al., 2011). Intellectual capital and innovation are becoming the foundation for creating competitive advantage. Therefore, at this time, we can see a distinct effort to integrate certain new leading performance indicators, such as leadership, training, education, innovation, capabilities, knowledge, and personal improvement into performance measurement systems. However, the focus is mainly on what should be measured today rather than what should be measured in the future (Kennerley \& Neely, 2003).

To be able to respond to above-mentioned changes, managers need comprehensive knowledge of new approaches in performance management and measurement. The main aim of this paper is to contribute toward building on such knowledge by designing a comprehensive process for performance measurement and management. The particular steps of this process are defined on the basis of an extensive review of the literature and a series of research studies carried out during the years 2011-2014 aimed at identifying the key elements of effective performance measurement and management systems (see Striteska \& Jelinkova, 2015). Using the results obtained, the critical element of performance measurement process development was determined, i.e., the choice and implementation of indicators that reflect all aspects of performance. An even more important aspect is utilizing the important information that has been acquired by measuring in the strategic planning process. Therefore, we decided to explore the extent to which financial and non-financial indicators are used, the degree to which top managers identify particular performance indicators as significant, and whether the information obtained from these measurements are used in the strategic planning process.

\section{Trends in Performance Measurement management System}

A contemporary performance measurement system must find a balance between indicators that are financial/non-financial, short-term/long-term, backwardlooking/forward-looking, shareholder-oriented/stakeholder-oriented, and leading/lagging (Kennerley \& Neely, 2002; Neely, 2005). This can cause practical problems, because companies often use too many poorly selected indicators (that do not drive performance and are poorly defined (open to manipulation), poorly measured (collected and analyzed incorrectly), and poorly applied (collected but not integrated into strategic decision-making) (Ittner \& Larcker, 2003; Pedersen \& Sudzina, 2012). 
At first, a strong critique of traditional performance measurement systems and managers' confidence in financial indicators led to greater emphasis being placed on "modern" financial indicators based on value management. However, as stated by Venanzi (2012) more than 10 years later, this scenario seems to have paradoxically changed only a little. International evidence as well as our surveys (Stríteská \& Jelínková, 2015) indicate that managers remain anchored to traditional financial measures, while other measures, such as EVA, are used rarely (Graham et al., 2005). This unchanged approach to financial performance measurement was also confirmed by a recent study conducted by the U.S. National Association of Corporate Directors, which determined that only $16 \%$ of managers use measures of economic value as financial metrics in compensation plans (Daly, 2011).

Next, through use of the balanced scorecard and EFQM frameworks, non-financial indicators are increasing and the literature has begun to stress their utility. Most research surveys reveal that non-financial indicators are more closely aligned to strategic initiatives, and can help employees focus on customer performance. Therefore represent the drivers of financial performance (Frigo, 2002). Performance measurement literature also assumes that the integration of non-financial indicators allows managers to better understand the relationships among various strategic objectives, communicate the association between employees' action and strategic goals, and set priorities based on those objectives (Said et al., 2003). It is also important to recognize that non-financial indicators are not free of limitations. As Chow (2006) stated, some non-financial performance indicators may be difficult to measure accurately, efficiently, or in a timely fashion. Other limitations are that they may be biased or ambiguous, easier to manipulate, measured in many ways that may change over time, time-consuming, and expensive (Eccles \& Mavrinac, 1995; Ittnerr \& Larcker, 2000). Moreover, they often differ between companies; for this reason, they are not suitable for benchmarking.

However, the question remains as to which performance indicators are optimal for measuring long-term corporate performance? In effective performance measurement systems, they must be based on organizational objectives, critical success factors, and customer needs - and they should change dynamically along with the strategy (Manoochehri, 1999). As recognition in the area of performance measurement grows, the researchers pose the question, "How can we best use the findings acquired by measuring performance for their management?" The indicators should be seen as part of fast feedback management systems and, at the same time, should be designed to stimulate continual improvement, rather than merely monitor strategic operations (Maskel, 1991). This could be seen as a current challenge for performance measurement and management.

In literature we can find a wide range of characteristics and features that must meet an effectively functioning performance measurement and management (Ghalayini \& Noble, 1996; Tsang, 1999; Kennerley \& Neely, 2002; Bititci \& Turner, 2002, 2006; Ittner et al., 2003; Nita, 2008). The relevant characteristics are summarized by Gomes et al. (2011) as follows:

- It must reflect relevant non-financial information based on key success factors of each business. 
- It should be implemented as a means of translating strategy and monitoring business results.

- It must accordingly change dynamically with the strategy.

- It must meet the needs of specific situations in relevant manufacturing operations, and should be long-term oriented, as well as simple to understand and implement.

- It must make a link to the reward systems.

- It should stimulate the continuous improvement processes.

- It must be clearly defined and have a very explicit purpose.

- It should allow a fast and rigorous response to changes in the organizational environment.

All these requirements are reflected in the performance measurement and management process that has been designed as part of this research.

\section{Objectives and Methodology of the Investigation}

This research study is composed of a number of sections that are linked thematically. First, the features of an effective performance management and measurement system are defined using the literature. Next, we have defined the key elements that are necessary for a performance management process that corresponds to global trends. These elements have been defined using case study analyses conducted for 46 companies during 2011-2013. A case study method was chosen because guides the researcher to better explanations for the process and outcome of the situation under study by analyzing the case (Tellis, 1997).

A total of 60 interviews were conducted with the mid-level managers (quality managers, HR managers, managers for strategic development) and top-level management (general directors, financial and sales directors) of selected companies. Content analysis was used to process the data. Semi-structured interviews were conducted based on the methodology and rules presented by Allhoff (2008) and Scharlau (2010).

By integrating these results, a diagram of a comprehensive process of performance measurement and management was designed, in which critical issues within contemporary performance measurement and management process, were identified. Because the inability to ensure that performance indicators are well-balanced is the most critical issue for these systems, this research study also covers this area. This part of research study is motivated by Stivers (1998) a Chow and Van der Stede (2006) who examined the use of financial versus nonfinancial measures and how managers weight corporate performance measures when evaluated performance.

Consistent with our focus in previous research studies, we limited our sample to medium (50-249 employees) and large (500 and more employees) manufacturing companies. The reason for this is that larger firms tend to measure more performance categories in comparison with smaller firms (Amber et al., 2004). Hoque and James (2000) also find a positive relationship between balanced scorecard measures and organization size. These findings indicate that large companies can be expected to have more sophisticated PMSes in comparison with SMEs. Second criterion for sam- 
ple selection was the long-term experience (more than 5 years) with performance measurement and management, which was determined using previously conducted secondary analyses. On the basis of these research studies we created research instrument that is composed of 33 financial and non-financial performance indicators that covered all key areas of business performance. Within each company, we directed this survey to financial managers and quality managers. The survey asked managers to identify performance indicators that are used in their company and to indicate their degree of importance and the extent of their usage in strategic planning, using a seven-point scale.

In this study, we ask three research questions:

1. Which specific indicators are used in the company's current performance management systems?

2. Which specific indicators do managers consider to be the most important for managing company performance?

3. Which specific performance indicators are used in the process of strategic planning?

\section{$4 \quad$ Findings and Discussion}

\subsection{Comprehensive Process of Performance Management and Measurement}

On the basis of integrating the results, a diagram has been drawn up for a comprehensive performance measurement and management process (see Chyba! Nenalezen zdroj odkazů.). 


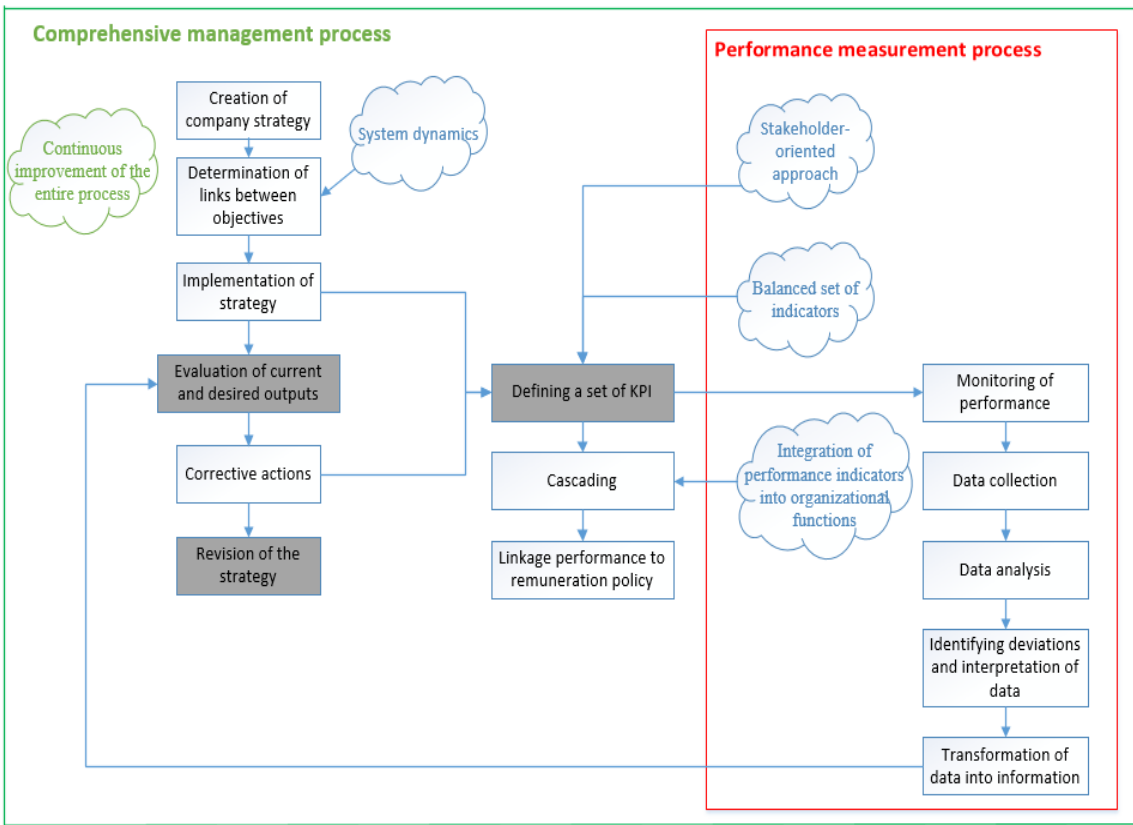

Fig. 1. Comprehensive Performance Measurement and Management Process.

The first step towards a comprehensive performance measurement and management process is to create a company strategy, which involves establishing a mission, a vision, and strategic objectives. Subsequently, it is necessary to establish relationships between goals using strategic maps, causal mapping, and system dynamics. Using these tools, it is possible to establish a missing objective or objectives (as well as a related performance indicator or indicators). In this way, the system provides a balanced perspective on the company and an understanding of the system's operation as a whole - of all of the system's variables and the relationships between them. Subsequently, it is possible to change these variables, influence their behavior, and manage them. The next successive step is to implement this strategy, i.e., to establish a balanced group of KPIs. The main requirement for attaining balance is to implement an approach focused on stakeholders, i.e., to analyze stakeholder interests and expectations while respecting individual aspects of the business processes. Only in this way is it possible to guarantee balance between the following indicators: financial/non-financial, leading/lagging, internal/external, stakeholder/shareholder-focused, and future/past performance.

Next, the strategic indicators must be described down to their lowest hierarchical level as they relate to the link between employee performance and reward policy, because the most frequent reason for managing performance is to influence employees' behavior, motivation, and rewards. What follow next is the collection, analysis, and interpretation of data, which includes identifying variations in performance. It is necessary to transform the data that was acquired into information, evaluate it in the context of the required outputs, and establish corrective measures. If it is determined that key performance indicators were defined incorrectly, it is necessary to modify 
and improve them. If the expected results were not achieved, it is necessary to trace the thought processes back to the strategy itself and change our original hypotheses on the strategy results. A culture that is continuously learning and improving performance is created by using a monitoring mechanism that has been set up in this way.

As part of this case study, critical issues were identified for the diagram, which has been set up in this way; these are highlighted. In particular, they concern attaining balance between the individual types of indicators and balanced coverage of all areas of performance. The managers themselves consider this area as the most problematic. The two next most critical issues, concerning evaluating outputs and subsequent strategy revision, closely relate to this.

\subsection{The usage and importance of financial versus nonfinancial indicators}

Knowledge of the use of new non-financial indicators is still limited in practice. Lingle and Scheemann's survey from 1996 found that financial performance indicators are included in regular management reviews at $98 \%$ of the surveyed companies, operating efficiency at $82 \%$, customer satisfaction at $76 \%$, and employee performance at 57\%. Chow and Van der Stede (2006) stated that, in a study carried out by Wm. Schiemann \& Associates, the executives widely acknowledged the limitations of traditional financial measures. Nevertheless, they still favored them over non-financial measures.

Our results demonstrate that the most commonly used indicators in the performance measurement system invariably continue to be profitability, the total cost ratio, cash flow, and sales growth i.e., financial indicators. However, a number of nonfinancial indicators are seen in the top ten, namely safety, the quality of product/service, and the satisfaction of customers and employees. Of the financial measures, productivity and financial stability ranked in top positions. This indicates that the ratio of financial to non-financial indicators is nearly equal among the top ten most frequently used. This also applies to the perspective of individual areas of performance measurement, because here we can find indicators that fall within all the perspectives used by the BSC method. Three more non-financial indicators follow: employee motivation, training/education, and process quality. More than half of the companies investigated here measure all of these indicators.

As is shown in the graph below (see Fig.2), non-financial indicators can be seen in lower positions as well - mostly in the area of customers and employees. In customer area indicator of satisfaction is already used routinely, on the contrary customer retention, which for example Nenadal (2004) identify as advance degree of excellence of performance measurement in relation to customer, monitor only $40 \%$ of companies. Unfortunately the same situation occurs in the area of internal processes where process quality is measured but indicators related to innovation, process time, or production flexibility continues to be underestimated. 


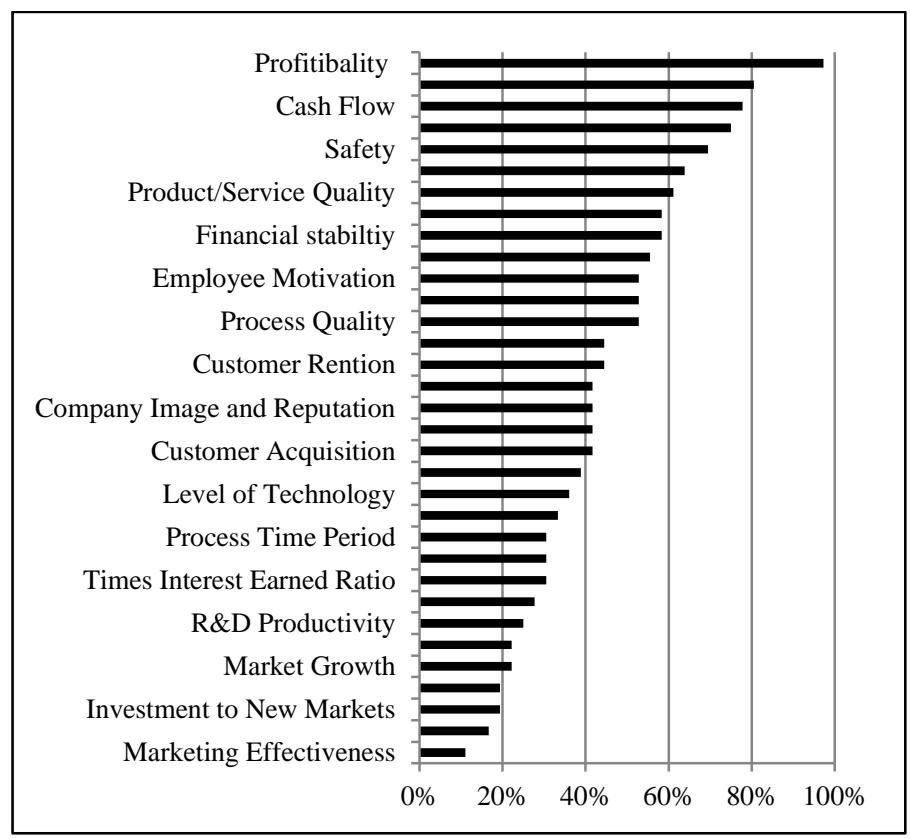

Fig. 2. The Relative Frequency of the Measures Used.

Despite the fact that typical financial indicators ranked among those most frequently used, it can be stated that they are complemented by so-called intangible measures at more than half of the surveyed companies. An interesting finding is that $40 \%$ of the companies also try to monitor indicators that are difficult to measure and concern company culture, image, and reputation.

A little less used are the indicators of core competencies, employee engagement, and marketing effectiveness, i.e., typical indicators focused on improvement. In 1998, research by Stivers et al., which was conducted on American Fortune 500 and Canadian Post 300 companies, revealed that customer service factors are considered the most important measures. On the other hand, factors in the categories of innovation and employee involvement were perceived to be less important in goal setting. Nearly 20 years later, our study has produced similar results, which is very surprising in the current competitive environment - where innovative capabilities and the quality of human resources, research, and technology are unquestionably considered to be the key to success.

Therefore, we also focused on investigating the fact that actual managers consider specific indicators to be the most important for managing a company's performance. From the graph below (see Fig. 3), we can see that nothing has changed significantly in the top rankings. Financial indicators are still considered to be the most important; these are supplemented by the typical indicators of customer satisfaction and product quality. 


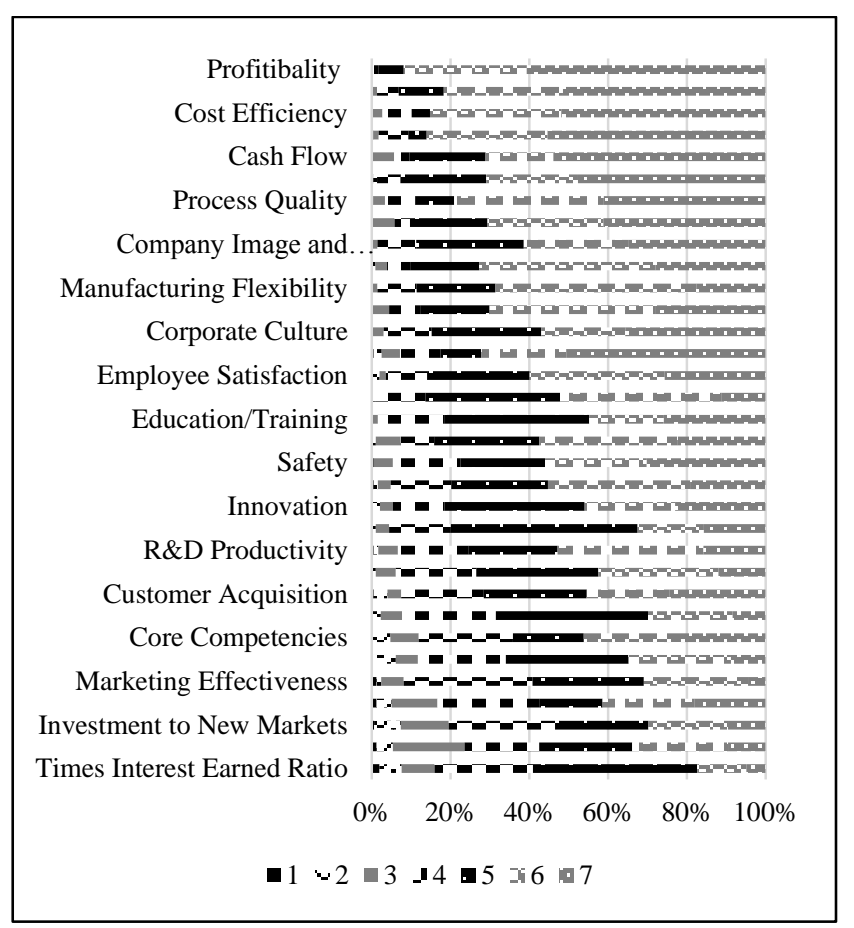

Fig. 3. The Importance of Specific Performance Indicators.

Only the indicators of process quality, company image and reputation are perceived to be more significant than the degree to which they are used. Thus, it can be seen that managers are now aware of the influence of these leading indicators on increasing company performance. On the other hand, the indicators of sales growth and safety are considered to be less important, despite being frequently used in performance measurement systems. Despite the unprecedented development of managerial techniques focused on continuous improvement, the indicators linked to employee engagement, innovation, core competencies, and process time have, without exception, ranked in the lower half of the graph.

As was stated in the literature review, it often happens in practice that information from performance measurement is not integrated into the process of strategic planning and decision-making even though it is available. This statement was only partially confirmed for the companies we investigated. The reason could be that the companies monitor performance mainly using indicators that can be easily measured. The information acquired using these performance indicators is then used in the process of strategic planning as well. Surprisingly, the only measure that indicated dissent was employee satisfaction. On the other hand, if companies monitor soft issues such as employee motivation and engagement or company culture, image and reputation, they use this information as part of the strategic planning process (see Fig. 4). 


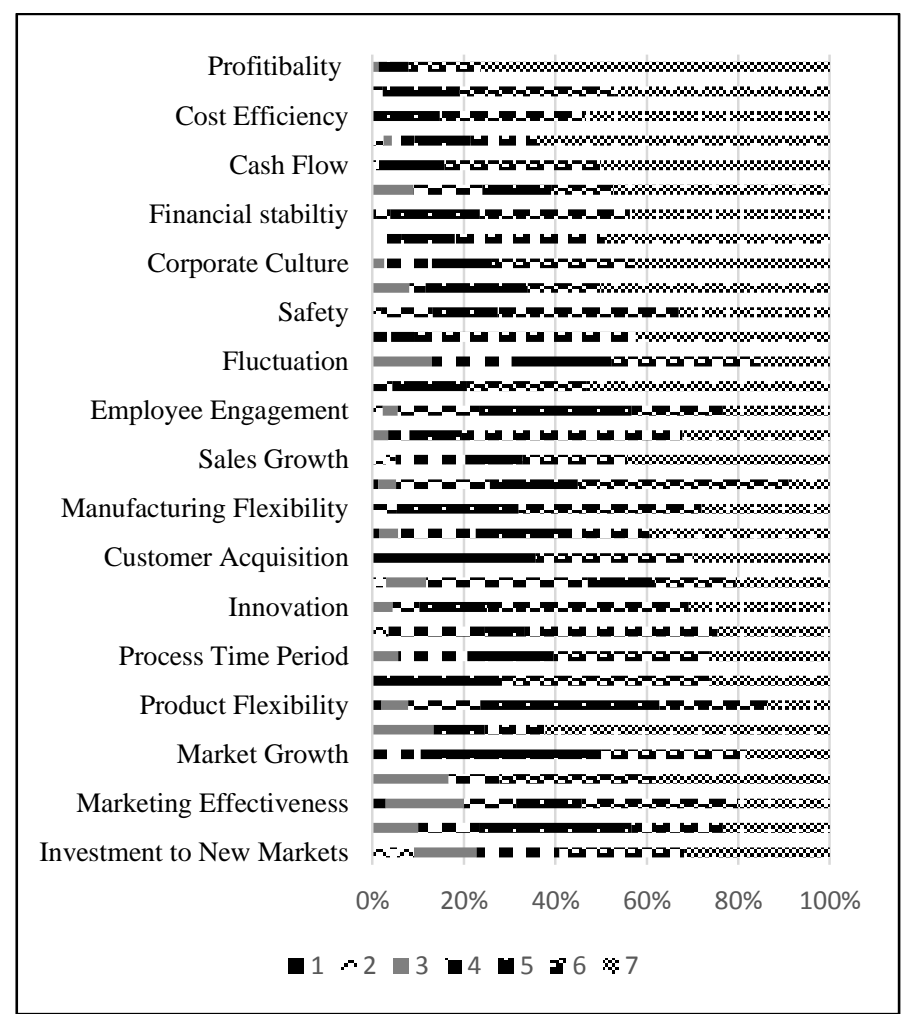

Fig. 4. The Degree to Which Specific Performance Indicators Are Used in the Strategic Planning Process.

\section{Conclusion}

A key requirement for success in today's tough competitive struggle is the ability to differentiate oneself from the competition. Constant change in the business and social environments changes the performance measurement system's requirements in conception and management methods as well as in methods for determining information and managers' professional qualifications. This type of turbulent environment in which companies operate leads to an attempt to understand how to use performance measurement system for continuous improvement and learning.

It is possible to state that the area of company performance measurement theory has been evolving in accordance with the development of global and business trends. The results of this survey demonstrate that, for the time being, the situation in the companies investigated here does not correspond to this development. These companies do not sufficiently react to developmental trends in this area and do not use the full potential of performance measurement system.

The results of the study reveal interesting implications for the mangers developing effective performance measurement and management system. In addition, the pro- 
posed comprehensive performance management process can contribute to the development of performance management knowledge. Compared to the previously conducted research studies our surveys revealed continuously increasing trend in the use of set of key performance indicators, which seeks to provide a "balanced" view of a company's performance evaluation. The results indicate that typical financial indicators are complemented by typical nonfinancial indicators from different areas of performance at more than half of the companies. The information from these performance indicators are also used into the process of strategic planning.

However, the approach is still unbalanced in favor of lagging indicators. The competitive-related performance aspects such as innovation, process time period, core competencies, and employee engagement are not sufficiently integrated in performance measurement systems. The disappointing for the authors of the survey is that these indicators are still perceived as less important by the managers. If we accept the widely recognized assumption that innovation and intellectual capital create competitive advantage, then it is essential that indicators related to these areas must be part of the strategic performance management system. In other words, still there a wide gap exists between what is used in practice and what is considered as effective in literature.

In general the companies need to pay more attention to indicators aimed at improving of performance that are currently used rarely. The managers need help to learning how to define these performance indicators and use the information derived from them in the strategic planning process. Only the integration of indicators reflecting important competitive aspects of performance can guarantee the balance between individual types of indicators and thus fulfil an essential prerequisite for effective performance management and measurement process.

\section{References}

1. Allhoff, D., Allhoff, W.: Rétorika a komunikace. 14th Ed. pp. 108-172. Grada, Prague, ISBN 978-80-247-2283-2. (2008).

2. Ambler, T., Kokkimaki, F., Puntoni, S.: Assessing marketing performance measurement in manufacturing companies, The British Acounting Review, Vol. 37, No. 3, pp. 261-297. (2004).

3. Bititci, U.: Measuring your way to profit. Management Decision, Vol. 32 No. 6, pp. 16-24. DOI: 10.1108/00251749410065088. (1994).

4. Bititci, U.S., Trevor, T., Begemann, C.: Dynamics of performance measurement systems, International Journal of Operations and Production Management, Vol. 20 No. 6, pp. 692704. DOI: 10.1108/01443570010321676. (2000).

5. Bititci, U.S., Carrie, A. S., Turner, T.: Integrated Performance Measurement Systems: Structure and Dynamics. Business Performance Measurement. Theory and Practice. Cambridge Universtiy Presess, Cambridge. (2006).

6. Bititci, U.S., Turner, T.: Integrated performance measurement systems: Structure and dynamics. In Business Performance Measurement: Theory and Practice. Cambridge University Press, Cambridge. ISBN 052-180-342X. (2002). 
7. Daly, K.: Corporate performance metrics to top board agendas. Finan Exec. Vol. 27, No. 1, pp. 50-53. (2011).

8. Dixon, J.R., Nanni, A.J., Vollmann, T.E.: The New Performance Challenge - Measuring Operations for World-Class Competition, Dow Jones-Irwin, Homewood, IL. 199 p. ISBN 9781556233012. (1990).

9. Eccles, R.G.: The performance measurement manifesto, Harvard Business Review, pp. 131- 137. (1991).

10. Eccles, R. G., Mavrinac, S. C.: Improving the Corporate Disclosure Process. Sloan Management Review, Vol. 36, No. 4, pp. 11-25. (1995).

11. Frigo, M.L., Krumwiede, K.R.: Balanced scorecards: a rising trend in strategic performance measurement", Journal of Strategic Performance Measurement, Vol. 3, No. 1, pp. 42-4. (1999).

12. Ghalayini, A. M., Noble, J.S., Crowe, T.J.: An integrated dynamic performance measurement systém for improving manufacturing competitiveness, International Journal of Production Economics, Vol. 48, No. 3, pp. 207-225. (1997).

13. Gomes, C.F., Yasin, M.M., Lisboa, J.V.: Performance measurement practices in manufacturing firms revisited. International Journal of Operations and Production Management, Vol. 31 No. 1, pp. 5-30. DOI: 10.1108/01443571111098726. (2011).

14. Hoque, Z. and James, W.: Linking balanced scorecard measures to size and market factors: impact on organizational performance, Journal of Management Accounting Research, Vol. 12, pp. 23-45. (2000).

15. Chow, CH.V., Van der Stede, W.A.: The Use and Usefulness of Nonfinancial Performance Measures. Management Accounting Quarterly, Vol. 7, No. 3, p. 8. (2006).

16. Ittner, C.D., Larcker, D.F.: Assessing empirical research in managerial accounting: a value-based management perspective, Journal of Accounting and Economics, Vol. 32, pp. 349-410. (2001).

17. Ittner, C.D., Larcker, D.F., Randall, T.: Performance implications of strategic performance measurement in financial service firms. Accounting, Organizations and Society, vol. 28, nos 7/8, pp. 715-41. ISSN 0361-3682. (2003).

18. Kagioglou, M., Cooper, R., Aouad, G.: Performance management in construction: a conceptual framework. Construction Management and Economics, Vol. 19, pp. 85-95. (2001).

19. Kennerly, M., Neely, A.: Measuring performance in a changing business environment. International Journal of Operations nad Production Management, Vol. 23, No. 2, pp. 213229. DOI 10.1108/0144370310458465. (2003).

20. Kennerly, M., Neely, A. A framework of the factors affecting the evolution of performance measurement system. International Journal of Operations and Production Management, Vol. 22, No. 11, pp. 1222-1245. (2002).

21. Lingle, J., Schiemann, W.: From balanced scorecard to strategic gauges: is measurement worth it? Management Review, vol. 85, pp. 56-61. (1996).

22. Maskell, B.H.: Performance measurement for world class manufacturing: a model for American companies, Productivity Press, Cambridge. 408 p. ISBN 9780915299997. (1991).

23. Manoochehri, G.: The road to manufacturing excellence: using performance measures to become world-class, Industrial Management, March-April, pp. 7-13. (1999).

24. Neely, A.: The evolution of performance measurement research: development in the last decade and a research agenda for the next. International Journal of Operation and Production Management, Vol. 17, No.11, pp. 1131-52. (2005).

25. Nenadal, J. et al.: Modely měření a zlepšování spokojenosti zákazníků: Od teorie k praxi. Národní informační středisko pro podporu jakosti. ISBN 80-02-01686-6. Prague. (2004). 
26. Pedersen, E.R.G., Sudzina, F.: Which firms use measures? Internal and external factors shaping the adoption of performance measurement systems in Danish firms. International Journal of Operations and Production Management, vol. 32, No. 1, pp. 4-27. (2012).

27. Robinson, H.S., Carrillo, P.M., Anumba, C.J., Al-Ghassani, A.M.: Review and implementation of performance management models in construction engineering organizations, Construction Innovation, Vol. 5, pp. 203-217. ISSN: 1471-4175. (2005).

28. Said, A.A., HassabElnaby, H.R., Wier, B.: An Empirical Investigation of the Performance Consequences of Nonfinancial Measures, Journal of Management Accounting Research, Vol. 15, pp. 193-223. (2003).

29. Scharlau, CH.: Trénink úspěšné komunikace: Jak uspět $\mathrm{v}$ každém rozhovoru v práci i osobním životě. pp. 33-57. Grada, Prague. ISBN 978-80-247-3301-2. (2010).

30. Stivers, B.P. et al.: How nonfinacial performance measures are used. Management Accounting, Vol. 79, No. 8, ProQuest, p. 44. (1998).

31. Striteska, M., Jelinkova, L.: Trends in Performance Management: Comparison and sumary of surveys. In Finance and Performance of firms in Science, Education and Practice. April 23 - 24, pp. 1443- 1479. ISBN 978-80-7454-482-8. (2015).

32. Striteska, M., Jelinkova, L.: The Characteristics of Effective Performance Measurement System: Case Study Analysis. Proceedings of Energy, Environment, Development and Economics. Conferences of INASE.org in Zakynthos, Greece, July 16-20, pp. 290-295. ISSN 2227-4359, ISBN 978-1-61804-324-5. (2015).

33. Tellis, W. M. (1997). Application of a case study methodology. The qualitative report, 3(3), 1-19.

34. Tsang, A. H. C., Jardine, A. K. S, Kolodny, H.: Measuring maintenance performance: a holistic approach. In International Journal of Operations \& Production Management, Vol. 19, No. 7, pp. 691-692. Doi: 10.1108/01443579910271674. ISSN: 0144-3577. (1999).

35. Venanzi, D.: Financial Performance Measures and Value Creation: The State of the Art, SpringerBriefs in Business. DOI: 10.1007/978-88-470-2451-9_2. (2012).

36. Wagner, J. (2009) Měření výkonnosti : Jak měřit, vyhodnocovat a využívat informace o podnikové výkonnosti . Praha: Grada Publishing, a. s.. Měření výkonnosti jako proces, pp. 36-39. ISBN 978-80-247-2924-4.

37. Yadav, N., Sushil and Sagar, M. (2013), Performance measurement and management frameworks: Research trends of the last two decades, Business Process Management Journal, Vol. 19, no. 6, pp. 947-970. DOI 10.1108/BPMJ-01-2013-0003.

https://doi.org/10.1080/00207543.2017.1404159 